\title{
El nacimiento de una forma de ser. Una nueva visión sobre la construcción de las mentalidades en el Montevideo colonial $(1726-1814)$
}

Resumo: O presente artigo analisa a vivência cultural da Montevideo antiga e de seu universo mental. Nosso conhecimento provém de várias fontes, como relatórios, cartas, testamentos e outros documentos. As evidências derivadas dos testamentos são muito valiosas por si só. Evidenciaremos as forças criativas presentes na formação da sociedade colonial.

Abstract: Our knowledge of the ancient Montevideo and their mentalities is derived from various sources. There are disjointed reports, papers, letters and testaments. The evidence from testaments itself is very valuable. The new elements show us an active and dynamic society. In this article we will appreciate the strengths implicated in their formation.

Palavras-chave: Montevideo. Mentalidades. Período colonial.

Key words: Montevideo. Mentalities. Colonial era.

Los primeros pobladores de Montevideo $^{1}$ fueron en su mayoría gente joven - con un promedio de edad de dieciocho años

Facultad de Humanidades de la Universidad de Montevideo, Profesor de la UM. E-mail: nelson03@adinet.com.uy.

1 Burgues era genovés; Carrasco, bonaerense; Rodríguez, santafesino; Artigas, zaragozano; Callo, francés; Sosa, chileno; Ledesma, paraguayo. Otros venían de Portugal, Irlanda, Sevilla, Corrientes, Salta y Granada. Predomina el canario pero la población no es homogénea. Del "primer núcleo hereditario" el 51,82\% era español y el $48,18 \%$ restante lo componían europeos no españoles y americanos. Del conjunto español un $57 \%$ es canario, un $10 \%$ andaluz, $7 \%$ castellano, $5 \%$ vizcaíno, $4 \%$ gallego y $17 \%$ de otras procedencias. El segundo contingente se compuso con bonaerenses y el tercero con brasileños, portugueses y paraguayos. Apolant, 1966, p. 48-58, 81-154, 839 .

Estudos Ibero-Americanos. PUCRS, v. XXXIII, n. 2, p. 35-50, dezembro 2007 
- que llegaba a una tierra nueva en la que "todo estaba por hacerse". 2 Como es obvio, estos colonos traían consigo sus propias costumbres y maneras particulares de pensar y sentir. La rudeza que tuvo su existencia cotidiana en los primeros años de vida de Montevideo, no los privó de sus valores, ni de su cosmovisión o de sus equipajes espirituales. No carecían de cultura ni tampoco de comunicación (Azarola Gil, 1976, p. 134). ${ }^{3}$ De hecho, sin una adecuada correspondencia entre las partes implicadas - individuos e instituciones - desde un principio no les habría sido posible salvar los desafíos que el medio les planteaba. A lo largo del periodo analizado (1726-1830) de un modo paulatino una mentalidad colectiva iría siendo modelada por los aportes sumados de europeos, africanos y aborígenes.

Estos últimos se encontraban asentados desde hacía miles de años, habiendo alcanzado diferentes niveles culturales. Está claro que los primeros colonos de la Banda Oriental de los siglos XVII - en Soriano, Colonia del Sacramento, Santa Lucía - y XVIII - en Montevideo y su entorno - no llegaron a un vacío cultural. Sin embargo, con el arribo del ganado y las plantas del hemisferio norte - colonización zoológica y botánica - así como de las nuevas poblaciones humanas se modificó sensiblemente el hábitat, la demografía y las costumbres de los aborígenes. Mientras los europeos reconstruían sus hábitos alimentarios y el paisaje de sus tierras, los antiguos pobladores de la Banda Oriental no solo veían cambiar su entorno sino que también se enfrentaban a una profunda crisis retados por nuevas y desconocidas formas de vida y producción. De hecho, las enfermedades y la incomprensión de las autoridades, tornaría agresivos a los grupos aborígenes - especialmente la macroetnia charrúa - hacia todo los colonos (Schiaffino, 1937, T. I). ${ }^{4}$

Sin embargo, los enfrentamientos y desencuentros culturales no impidieron que los primeros montevideanos incorporaran a sus cuentos populares elementos tomados de las leyendas indígenas, que algunas armas - como las boleadoras - fueran empleadas por los criollos en batallas trascendentes - como Las Piedras -, que la

2 De un total de 131 personas: 61 eran menores de 15 años (46,5\%), 53 tenían entre 16 y 39 años $(40,5 \%)$ y 17,40 años o más (13\%).

3 Azarosa, op. cit., p. 134: "Carecían de instrucción y de cultura. [...]. Eran labriegos rudos, ignorantes y virtuosos. [...]. Toda cooperación mental era ociosa en la función puramente material y física de aquellos hombres". Apolant, p. 6-7: "Vivieron una vida ruda, primitiva, carente de toda comodidad, civilización y cultura, durante aquellos primeros decenios" (periodo 1726-1750). Azarola y Apolant manejan un sentido restringido de cultura.

4 Los investigadores proponen fechas entre los 28.000 y los 10.000 años a. p. 
música aborigen se mezclara en el folklore oriental, o que los colonos integraran a su farmacopea tradiciones herborísticas nativas, su aplicación en remedios y hasta su conexión con un mundo superior. No asombra que aun en la primera mitad del siglo XIX los curanderos fueran más populares que los médicos.

Por su parte, el ingreso episódico de negros esclavos provenientes de varios lugares de Mozambique, Senegal, Sierra Leona, aportó singulares componentes de tradición milenaria a la nueva sociedad en formación (Bentancur, 1997, p. 257). Como en el caso de los aborígenes, no pocas prácticas africanas como los bailes se difundieron rápidamente entre la población blanca. Y no pocos europeos y criollos, vistas las carencias, harían pareja con mujeres de color o con aborígenes, dando lugar a grupos mestizos.

A todo esto hay que agregar que para la segunda mitad del siglo XVIII y comienzos del XIX, nuevos contingentes provenientes de Europa y América harían su ingreso en el contexto cultural montevideano, atraídos por el progreso comercial, dándole a la ciudad el incremento demográfico y la modificación de su fisonomía social y sicológica (Bentancur, 1997, p. 390). En los hechos, la condición portuaria de Montevideo favoreció el tránsito de ideas desde todas las comarcas de la región y de ultramar, transformando a la ciudad en un "gran bazar de novedades", punto de arribo de gente común, de profesionales y científicos de diversas áreas.

Rapidamente esbozado este primer panorama permite apreciar la existencia del juego de fuerzas implicado en la formación de una sociedad dinámica, no carente de contradicciones, pero con una mentalidad compleja en la que es posible reconocer influencias diversas. Pese a que la sensación de identidad y pertenencia a un grupo descansa - ayer como hoy - en una distinta conformación mental, los sistemas de pensamiento puestos en movimiento y la experiencia cotidiana de los actores sociales, produjo interacciones que modificaron la mentalidad del otro y condicionaron el pensamiento grupal. Por todo esto y más, la época colonial no puede ser considerada nunca en ningún aspecto una época estática (Azarola Gil, 1976, p. 164). Ni material ni intelectual ni socialmente. El dato clásico proveniente de la tasación de bienes realizado en 1751 para costear la guerra contra los minuanes, revela una sociedad que ya tiene "sensibles" diferencias de fortuna, nivel social y ubicación laboral. A poco más de veinte años de fundada, en Montevideo se perfilaba una tendencia a la diferenciación, lo que implicaba que se producían 
cambios en las condiciones materiales de sus habitantes ${ }^{5}$ (Bentancur, 1997, p. 15).

\section{Oralidad y cultura escrita}

En aquel entorno socio-cultural, la enérgica comunicación oral pautaba la interacción entre los habitantes de Montevideo. Casi está de más decir que la misma desempeñaría un rol clave en la socialización de los individuos y en la difusión de sus ideas. Este predominio de lo oral se ve en la importancia concedida a la memoria en la educación. Uno de los requisitos fundamentales para graduarse de bachiller era memorizar el saber adquirido para "lucirlo" en el examen. Y aunque los manuscritos desempeñaron un rol privilegiado en la conservación y transmisión del saber a medida que los libros impresos se difundían, funcionaron como un soporte más de la memoria y no un sustituto de ella.

Desde sus primeros años de vida, la burocracia oficial montevideana procuraría alfabetizar a la sociedad en desarrollo y extender sus controles administrativos a la vida cotidiana, superando las "deficiencias" que le planteaban los funcionarios que no sabían leer y escribir o apenas rubricar. Lo que convertiría en prototípico el rótulo "firmaron los que supieron" estampado en muchos escritos oficiales del periodo (AGN AGA 1742, Lib. 6, fol. 199). ${ }^{6}$ Como parte de esta burocracia alfabetizada el primer y dos veces gobernador de la ciudad, José Joaquín de Viana (1749-1764, 1771-1773) figura social paradigmática del Montevideo colonial, marcó claramente la escisión entre alfabetizados y analfabetos en sus cuadros administrativos al señalar en 1755 que: "No pocos de los que componían el Cabildo no sabían leer, ni escribir, y a este tenor la ilustración ${ }^{7}$ de sus entendimientos no es la necesaria para determinar las materias judiciales que resuelven en las disputas dar armas y quitar a otros distinguiendo los casos con la razón y los preceptos del derecho" (AGN AGA, 1755, C. 7,C. 4, Leg. 4, Oficio Cabildo). ${ }^{8}$

5 Las mayores fortunas: Francisco Alzáibar (86.887 pesos), Juan de Achucarro (12.275) y Antonio Méndez (7.480). De los 169 censados, el 60\% (102) no superan los 1000 pesos.

6 Se tomaban providencias para obtener recursos para construir el Cabildo.

7 La palabra "ilustración" tiene una larga trayectoria de uso en el vocabulario montevideano. Aparece en los primeros documentos del Cabildo (1732) y la emplea Viana como "iluminación, claridad, resplandor, reflejo", "declaración, explicación, amplificación del algún criterio".

8 Véase también: AGN AGA 1732. Lib. 6, f. 59. 
En otras palabras, al no dominar la lectura los cabildantes perdían el acceso al conocimiento directo de autores y obras que podían educar su entendimiento. Su saber se remitía a lo oído, a la tradición legal oralmente transmitida; la cuál aprehendieron mal o bien como oyentes en la lectura de la correspondencia oficial. Pero aquello no era suficiente. Más si se trataba de interpretar una norma o aun justificarse para desobedecerla - como lo intenta Viana - citando la autoridad de Aristóteles, del jesuita Suárez y del jurista Molina en un triángulo con el que invoca tradición intelectual, religión y derecho.

Por esto, quien sabe leer tiene en la época colonial un poder de decisión fundamental sobre los que no saben. De hecho, la carencia se vuelve descalificadora a fines de la década siguiente cuando el gobernador Agustín de la Rosa (1764-1771) ordena - ando viejas normas indianas - el futuro quienes sean designados para cualquier cargo público deban poseer "los aditamentos de saber leer y escribir" (1768): "ordenó su Señoría al mismo tiempo que de aquí en adelante se tuviese presente que para ningún empleo ni cargo público se eligiese persona que no poseyese precisamente los aditamentos de saber leer y escribir, la cual disposición la prevenía para que se observase sin alteración por ningún motivo, ni con pretexto alguno".

La razón esbozada, con base en la experiencia recogida, es la de que: "avisa la experiencia los inconvenientes que se siguen de recaer cualesquiera de los dichos empleos en personas que absolutamente carecen de dichos aditamentos" (AGN AGA, 1768, Lib. 9, f. 238). Os inconvenientes administrativos generados por quienes no dominaban la cultura escrita servían de estímulo a la búsqueda de una mayor y más generalizada educación. Por supuesto, esta exigencia no era casual. Se daba en el marco de renovación de la burocracia montevideana incentivada por el Reglamento de Comercio Libre de 1778. Desde allí la administración de la ciudad alcanzaría su más alto índice de complejidad mientras crecía materialmente. La nueva Real Hacienda, la Real Aduana (1779), el incremento de los servicios públicos - y salud, un hospital con trescientas camas y otro administrado por la Hermandad de Caridad - arición de los escribanos públicos y de la Junta de Temporalidades municipal desde la década del 70 del siglo XVIII, ${ }^{9}$ el tribunal del Real Consulado (1812), la Real Audiencia; la constitución del Cuerpo de Blandengues (1798) y más, son revela-

9 El primer escribano, Cosme Álvarez fue nombrado por el gobernador Joaquín de Viana. 
dores de la complejidad lograda. A lo que hay que sumar algunos hechos aislados pero importantes como la larga permanencia del virrey Juan José de Vértiz en Montevideo junto al núcleo central de la administración virreinal.

De este modo al promediar el siglo XVIII se desarrollaba una batalla silenciosa entre la cultura oral y la escrita en toda la Banda Oriental. No llama la atención que veinte años después del incidente entre Viana y el Cabildo (1778), el corregidor de Santo Domingo de Soriano diera cuenta al Virrey en Buenos Aires de su intención de mejorar la condición cultural de su pobre pueblo, el cuál estaba formado por un centenar de ranchos y algunas casas de ladrillo cementado con barro y cal, donde los hombres con educación formal eran muy pocos. El corregidor expresaba que desde su regreso: "a este Partido (- el pueblo de Soriano -) he procurado inspirar a su vecindario aquellas precisas luces que con el tiempo proporcionan un buen orden y sacan a los naturales de su rusticidad" (Lockhart, 1967, p. 37).

Como en Montevideo, la mayoría de los hacendados de Soriano no sabían leer ni escribir. ${ }^{10}$ Pero es interesante que al asociar la educación - bajo el entonces popular rótulo "luces" - con el "buen orden" social, el Corregidor hacía indirectamente una valoración de la educación como agente de progreso y de su ausencia como factor de desorden e ignorancia. Sin embargo, no debe creerse que esta circunstancia era un impedimento para el progreso personal. La preeminencia de la cultura oral no supone necesariamente primitivismo. A modo de ejemplo, el vecino Francisco Macaya como otros - fue en el Montevideo de 1803 un comerciante próspero con más de una década de actividad pese a que no sabía ni siquiera firmar (AGN AJ PEP, 1804, T. 1, fs. 382-385). No obstante, por uno $\mathrm{u}$ otro medio la burocracia estatal intentaría extender la cultura escrita hacia todos sus rincones. Así en 1809, imbuida por un espíritu progresista, una representación de vecinos montevideanos interesada por el desarrollo cultural de la ciudad escribiría al Cabildo sobre su preocupación en cuanto a la educación montevideana: "Escasean aquí Señor los hombres de Letras porque un Pueblo naciente no puede tenerlos y aunque según el genio aplicado [...] esperamos que los tendremos antes de mucho, por ahora es preciso aprovecharse de aquellos pocos sujetos que a más de poseer un buen fondo de luces quieren someterse a la pesada tarea de una escuela" (AGI 1809. Buenos Aires, 317. S/foliar) (Pierrotti, 1998, p. 98).

10 Según dijo el Corregidor Ballesteros en 1791. Azarola Gil, L. op. cit. p. 72. 
Según ellos la alfabetización de la sociedad requería de "genio aplicado" y de "hombres de letras" con "un buen fondo de luces". Es obvio que la preocupación social manifestada tenía su origen en la falta de medios suficientes para sacar a los naturales del ambiente menospreciado de cultura oral.

\section{Aspectos de la progresiva alfabetización}

La transmisión de la capacidad de leer y escribir en la Banda Oriental marchó en función del desarrollo de la educación y de la difusión del libro. Contar firmas solo dice cuanta gente saber firmar pero no alcanza para dar una idea del nivel de familiaridad de la sociedad con la escritura. La expansión de la mentalidad alfabetizada en la vida cotidiana se aprecia en parte a través de la "popularización" de objetos típicos del quehacer escrito como resmas de papel, tinteros, cartucheras, reglas y compases. Entre los pedidos diarios hechos a los barcos españoles anclados en puerto al Arsenal de la Marina, figuran resmas de papel y cuadernillos en los cuales se dibujaban planos o señales, se redactaban instrucciones, partes diarios, bitácoras o meras papeletas de consumo (AGNA S.9,20-3-9, 1767, Arsenal Marina). Los libros contables y las libretas de almacén eran usados a diario por los comerciantes minoristas y mayoristas como consta en el AGN. ${ }^{11}$ La memoria se veía ayudada en su función de registro de solicitudes, transas o contratos. Esta progresiva imposición de la burocracia en el ámbito castrense, civil y religioso pauta su éxito. Durante las primeras décadas la única burocracia que conoce la ciudad es la militar. Esta "no desapareció durante todo el periodo colonial, a pesar de la conformación paulatina de elencos burocráticos de la Real Hacienda y Gobierno". A medida que la urbe creció centró sus actividades en el puerto y la administración. La burocracia civil progresó paralelamente a los servicios públicos. La eclesiástica tuvo por baluarte la oficina jesuita establecida en 1746. En ella se hallaban recibos de alquiler, libros contables, instrucciones internas, correspondencia oficial, cuadernos, testamentos, catálogos y listas de bienes. A nivel individual, la multitud de documentos y recibos de comerciantes como Francisco Medina, ordenados en carpetas y fojas innumerables, muestra cómo la administración avanzaba (AGN AGA, A. P., 1786, C. 121, f. 51).

11 Juan Nuñez, 7 de abril 1767; Joseph Cruces 19 de set. 1767; Calisto Genes, 18 de oct. 1768. 


\section{Oralidad y vida social}

Mientras esta lucha interna se gestaba, en el marco de lo cotidiano la vida social montevideana luce un vigor y dinamismo muy intensos, como lo reconocen los viajeros. Especialmente las mujeres merecieron reiterados elogios. Así según se indica, las mujeres africanas de Montevideo eran muy charlatanas, "transmisoras de dichos" y de todo cuanto de interés ocurriera en su entorno. El francés Pernetty (1764) tras señalar con admiración lo amistosos que eran los españoles montevideanos, agregaba que "las mujeres tienen en su casa por lo menos tanta libertad como en Francia. Ellas hacen sociedad de muy buen grado y no se hacen rogar para cantar, bailar, tocar el arpa, la guitarra, el tuorbe o el mandolino. Son en esto mucho más complacientes que nuestras francesas [...]. [Los hombres] se juntan con algunos amigos, hablan dos horas, sin decirse nada, fuman, toman mate y vuelven a montar a caballo de regreso" (Revista Histórica, 1946, T. 6, p. 274). Es interesante que décadas después el inglés John Mawe (1805) coincidiera con las observaciones anteriores y afirmara que en general las montevideanas se vestían con criterio para cada ocasión y que "las mujeres son generalmente afables y sociables, les gusta extraordinariamente la toilette en que ponen mucha elegancia. Para estar en casa han adoptado el modo de vestir inglés, pero cuando salen van casi siempre de negro y siempre con un gran velo o mantilla. A la iglesia acuden solo con vestidos de seda negra guarnecidos de muchas franjas. Les gusta singularmente la conversación y su vivacidad natural les dispone a ello y hacen muy buena acogida a los extranjeros" (Arredondo, 1959, p. 83).

Así mismo el comerciante inglés Henry Porter expresó su sorpresa por la forma de bailar y vestir de la mujer rioplatense: "Lo primero que se le enseña a las jóvenes es a caminar y bailar bien [...]. Su vestimenta y andar son tan gráciles que generalmente superan a sus vecinas brasileñas" (Porter, 1995, p. 50). Así también, Alcide d'Orbigny, científico del Museo de Ciencias Naturales de París (1827-1828) se admiraría del aire sobrio de las mujeres orientales vestidas de "amazonas" con sombreros adornados con "hermosas plumas de avestruz" que encontró cerca del arroyo Las Vacas (San José): "Las mujeres estaban vestidas como todas las amazonas, es decir, que llevaban un sombrero de hombre, adornado con hermosas plumas de avestruz, que les sentaba bien. Les ofrecimos vino o aguardiente; prefirieron este último licor y se 
pasaron el vaso de boca a boca hasta vaciarlo. Luego se retiraron." (D’Orbigny, 1839, p. 50).

No puede pasarse por alto, sin embargo, el comentario mordaz y la crítica de los hombres a la afabilidad femenina o incluso a su capacidad intelectual. En el Telégrafo Mercantil (1801) se diría que "el artesano, la mujer, el niño y el holgazán no son capaces de leer un libro de volumen; y como (los) periódicos son cartas, entretenidos y abundantes" era más probable que los leyeran. Y considerando que no pocos viajeros eran también espías, el Capitán de Fragata español Juan Ángel Michelena (1814) se quejaría con tono despectivo de "las mujeres todo lo hablan" exponiendo cuestiones que se prefería mantener en secreto.

Sin embargo, persisten los juicios favorables. Y lo más destacable es esa disposición a la comunicación y la diversión como elemento identificador de su personalidad. Así cuando llegó a Montevideo el francés Arsene Isabelle - quien tendría una importante trayectoria en Uruguay - le causó impresión la amabilidad de sus pobladores, su "mucho espíritu" y su apariencia personal que ofrecía "encantos reales" (Isabelle, 1832). No sorprende que dos años después el naturalista inglés Charles Darwin - más allá sus estampas negativas - se manifestara impresionado por los modales, la cortesía y el gusto de los montevideanos de "todas las capas de la sociedad" (1832): "Cuando comenzamos a conocer la vida social de estos países, hay dos o tras cosas que nos impresionan: la cortesía y dignidad en los modales que hallamos en todas las capas de la sociedad, el excelente gusto que demuestran las damas en el vestir y la igualdad entre las clases sociales" (Barrán y Nahum, 1986, p. 133).

También es de tener en cuenta el talento festivo de los negros africanos, que se exhibía durante el año contagiando a los montevideanos, hombres, mujeres e incluso niños que se familiarizaban con sus vivos ritmos y danzas apenas podían pararse, según dice Pernetty (1763): "Hay un baile muy vivo y lascivo que se danza a veces en Montevideo; se le llama Calenda, y tanto los negros como los mulatos, cuyo temperamento es ardiente, les gusta con furor. [...]. Los españoles bailan como ellos [...] sin el menor escrúpulo. El gusto es tan general y tan fuerte, que los niños mismos se ejercitan desde que pueden pararse". Sin embargo, este relativo idilio social - "tan general y tan fuerte" - no perduraría ya que décadas después los vecinos de Montevideo pedirían la prohibición de "los Tangos y otros bailes de los negros" (1808) porque ofendían la sensibilidad general. 
En aquella sociedad variopinta los lugares de encuentro social, es decir las tertulias, las fiestas nocturnas, las librerías y cafés eran significativos. Las tertulias eran sitios idóneos para el intercambio de ideas. Cuanto llamase la atención o produjera preocupación pasaba por los causes de estos "foros" domésticos, donde era frecuente la lectura en voz alta de libros y diarios. Esta oralización del mensaje escrito tuvo efecto en la comprensión y la sensibilidad de los orientales. Razonando sobre la idiosincrasia criolla el comerciante y agente inglés John Robertson - que en 1815 se entrevistó con Artigas en Purificación - se admiraba de la viva imaginación y elocuencia de los rioplatenses que eran cualidades casi naturales en ellos. Las mismas surgían según él de sus hábitos de tertulia donde se conversaba diariamente. "La imaginación vivaz es casi natural en los habitantes [...] se expresan con una fluidez, si no elocuencia, a que nosotros (- se refiere a los ingleses -) aspiramos rara vez. Esta facilidad ha surgido de sus tertulias o hábitos de conversación. La imaginación del sudamericano trabaja siempre" (Robertson, 1839, p. 33).

Es posible asimismo que las fiestas nocturnas - donde se hacían negocios - hayan sido clave para la discusión de las nuevas ideas políticas y sociales en boga y el afianzamiento de intereses económicos. Durante la ocupación de Montevideo (1807) los ingleses ofrecieron una gran celebración para conquistar a las autoridades y comerciantes locales y ganar adhesión ideológica para la libertad de comercio (The Southstar, 1807, p. 1). Solo dos años después cuando las heridas emocionales causadas por las invasiones todavía estaban vivas, los comerciantes británicos William Mann y Jorge Dickson organizaron otra gran fiesta o "convite" - aunque de menor importancia al de 1807 - con el motivo de celebrar el cumpleaños del rey de Inglaterra en la Fonda de Francisco Estrázulas. En la comida se hizo ostentación de carne de ternera, pavos, patos, perdices, chanchos, pollos, jamones, tocino, chorizos, salchichas, salchichones, verdura, huevos, mantequilla, aceitunas, anchoas, melones de Valencia, pasas, nueces, higos, manzanas, dulces, duraznos, sidra, vino, cerveza y licores; los que fueron dispuestos liberalmente. Más allá de su corto éxito, lo que buscaban era crear una nueva imagen de los negocios británicos (1809). ${ }^{12}$

El otro referente en la difusión social de las ideas fueron las librerías, como la que el español José Fernández Cutiellos fundara en 1796 o antes, siendo por mucho tiempo la única de la ciudad.

12 La fiesta como institución social nunca fue ajena a la vida montevideana. 
Allí solían encontrarse comerciantes, funcionarios públicos y doctores como Dámaso Larrañaga y Francisco Antuña, entre otros. A partir de las nueve de la noche Cutiellos era visitado todos los días por sus amigos: "La Casa de su habitación, particularmente, desde las nueve en adelante, pues desde esa hora siempre acostumbra estar en su casa y no volver a salir" y era visitado por "Don Dámaso Larrañaga y Don Manuel Antuña, que son los que por lo regular van todas las noches a la Casa Librería" (AGN AGA 1812, Lib. 249, f. 23). La posterior vinculación del librero y de Larrañaga en la Revolución oriental, no deja dudas sobre el tipo de asuntos que se conversaban. El Gobierno revolucionario de Buenos Aires reconoció las virtudes de Fernández por los "servicios prestados al Ejército de la Patria en la banda oriental, y quebranto que sufrió en sus intereses en la Plaza de Montevideo, por haberse sustraído de la dominación de los Españoles a ella" (AGNA BA, 1814-15, Acuerdos del Cabildo, Serie IV, t. 7, LXIX-LXXIV, p. 614).

Posteriormente los cafés ocuparían los espacios de diálogo que antes habían sido privilegio casi exclusivo de las tertulias. Las pulperías - desde muy temprano - habían oficiado de puntos de reunión y discusión, encuentro o desencuentro. Pero a partir de la segunda mitad del siglo XVIII los cafés impusieron una nueva modalidad en la comunicación de las ideas. Por ejemplo, el café de Mariño fue el punto de encuentro de los montevideanos que propiciaron la creación de la Junta de Gobierno de 1808, al saberse que Napoleón había invadido España. "Estando en el Café de Mariño, el Ayudante de la Plaza don Matías de Larraya [...] fue disfrazado a conmover a algunos individuos [...]. Al día siguiente se celebró un Cabildo abierto, en donde se acordó el Establecimiento de una Junta de Gobierno" (Documentos Junta Montevideana, 1808, p. 18-25).

Desde el Café partió un grupo de hombres que coreaba "Muera Liniers, muera Michelena y viva Elío" compuesto - según los partes - por oficiales y "vecinos blancos de la clase más ínfima con unos cuantos esclavos", los cuales se pasearon por las calles al son de una música marcial. El Capitán José de Posada atestiguaría que "por la voz general del Pueblo se sabe que los principales Alborotadores salieron del café de Comercio". El Capitán de Fragata Juan Ángel Michelena enviado por el virrey Liniers a sustituir a Xavier de Elío en el gobierno de Montevideo, fue muy mal recibido y por seguridad salió de la ciudad. Según el Capitán de Fragata José de Obregón, el gobernador Elío habría hecho circular por la ciudad una carta sin firma que "después oyó en el café de Mariño de aquel Vecindario repetir la pública lectura de este 
papel". El Teniente Manuel de la Iglesia afirmó "que todo el mundo tuvo copias de esta carta, la cual se leía en los Cafés y casas particulares" (Documentos Junta Montevideana, 1808, p. 18).

Más allá de lo implicado en el episodio, lo destacable es el funcionamiento de los circuitos de comunicación, los "cafés y las casas particulares". Sabemos que los ecos de los debates habidos en las aulas universitarias de Charcas (Bolivia) y Córdoba (Argentina) a las que asistieron desde temprano no pocos orientales, alcanzaron a la propia sociedad colonial montevideana. El primer doctor oriental, Fernando Martínez, se recibió en Derecho en Charcas (1743) y de allí en adelante varios jóvenes orientales recibieron títulos y volvieron a sus hogares, llevando consigo las discusiones universitarias. Esto lo confirma Robertson cuando dice, "acuden a las universidades locales - los jóvenes de las distintas y lejanas ciudades y pueblos del continente en procura de la educación que las universidades podían dar y PARTICIPAN a sus LUGARES NATIVOS y a sus FAMILIAS, lo que obtenían en el curso de educación a que habían estado sometidos".

Tanto la familia como el núcleo social al que pertenecían los estudiantes participaba de algún modo de su educación al convertirse en receptores del mensaje universitario, receptoras distorsionadas o no de las discusiones europeas. El mensaje mismo no caía en el vacío sino en un medio con sus propias tradiciones, costumbres y controles institucionales e ideológicos. Lo que hacía inevitable la relectura del mensaje original. Robertson comentaría esta discrepancia al decir que al rioplatense: "Le oímos discurrir en términos brillantes y elocuentes sobre 'libertad civil', 'libertad de imprenta', 'educación liberal', 'derecho constitucional' [...]. Sin embargo, las ideas que acuden a nuestras mentes [...] son en verdad diferentes de las que surgen en el cerebro de los sudamericanos" (Robertson, 1839, p. 34).

Otros ejemplos, apuntan a canales de divulgación diferentes, incluso clandestinos. En 1803 el poder de la comunicación oral se haría sentir desde la población esclava negra y libre - 30\% de los montevideanos - al margen de la cultura alfabetizada. Aquel año el gobernador José Bustamente y Guerra se enfrentó a este grupo que tras su contacto con los mulatos libres de los barcos franceses decidieron amotinarse y formar una población en los montes: ${ }^{13}$ "Habiendo observado su señoría el orgullo y avilantez demasiada que habían tomado los negros esclavos dimanado sin duda este procedimiento del TRATO, COMUNICACIÓN y ROCE con los de su

13 Napoleón decretó la abolición de la esclavitud en las colonias francesas. 
clase que tripulaban las muchas EMBARCACIONES FRANCESAS que han tenido introducción en este puerto [...] ha crecido excesivamente en los referidos negros el desorden y el orgullo, y la insubordinación a sus amos [...]. Ha llegado ésta a tanto grado en ellos que en estos últimos días hicieron entre libres y esclavos una secreta convocatoria en la que determinaron ponerse en huida, no sin municionarse, [...] con el designio de seguir su ruta al Monte Grande, y formar en lo intrincado de él una población, según ha llegado a trascender por noticias [...]".

Instruidos por sus pares del Caribe estos esclavos decidieron huir de sus amos para conseguir su libertad en lo "intrincado del bosque", de modo similar a lo hecho por grupos negros de Río Grande (Brasil). En vista de "los excesos de insubordinación que se notan en los Negros así libres como Esclavos, y demás gente de otras cartas". Bustamante ordena "fijar el Rollo en la plaza pública para que en él sean castigados con la pena de azotes los transgresores" (AGN AGA, 1803, C. 272, c. 2, doc. 24). El rollo español era una horca de piedra en forma redonda o de columna donde se disponía el azote de los negros rebeldes (Diccionario de Autoridades, $1726-34$, p. 634). El gobernador entendía que la vergüenza pública sería para los negros un peor castigo que la muerte. En especial, lo que intentaba a toda costa era evitar que se produjera un desorden social (Frega, 1998, p. 290) que inspirara la insubordinación criolla: "Máxime en esta ciudad donde puede afirmarse que es menos el número de blancos que de negros, lo que parece les ha dado brío e inspirado la perversa idea de hacer y verificar nueva unión y conmoción". Es necesario el castigo público para los rebeldes pero "guardando también moderación y comedimiento con los espanoles, para que no se trasplanten y propaguen en esta ciudad [...] los levantes y motines que por la adulterada mal introducida política en punto a la esclavitud [...] (ha ocasionado) terribles y funestas consecuencias".

Dejando de lado las diversas implicaciones que presenta este tema, lo que resulta de mayor trascendencia es el poder ejercido por la comunicación oral en la conducta de los grupos humanos coloniales. No se trata de gente que en un marco institucional o por medio de un libro o de cualquier otro impreso distribuido extensamente se haya puesto en contacto con el pensamiento liberal del siglo XVIII y deseara abolir la esclavitud. Es en realidad el sector más bajo de la sociedad - marginado de la educación formal - el que se ve conmovido por ideales de libertad e independencia, interpretados desde su propia óptica. El suceso en 
sí queda como prueba del poder movilizador de la comunicación oral (Araujo, 1944, p. 16).

\section{Una cultura en crisis (1811-1851)}

La confianza que los montevideanos del siglo XVIII habían tenido en los futuros progresos de su ciudad chocaría duramente con las nuevas realidades políticas y económicas apenas abierto el siglo XIX (Pierrotti, 2005, p. 4). La revolución oriental (1811-1816), las luchas por la independencia del Brasil (1816-1828) y más tarde la Guerra Grande (1839-1851) sumieron a la Provincia en un estado caótico de destrucción material, a medida que se producía el cambio de roles sociales. Esto causó una profunda depresión general que llevó a la pérdida de valores y esperanzas. No sorprende que muchas de las más negativas observaciones hechas por los viajeros sobre las actitudes de los orientales provengan del siglo XIX. En el informe que el inglés Thomas Hood elevara a su superior George Caning - Ministro de Relaciones Exteriores británico - en 1815 se lee que los orientales: "Desde la más tierna infancia se les enseña el fraude, el engaño, la mentira y la adulación. La integridad, la verdad y el cabal cumplimiento de los compromisos no forman parte de su educación. Ellos consideran estas cosas como prejuicios europeos [...] y al hombre que sacrifica sus intereses a su reputación, y al sentido de sus obligaciones morales, lo consideran un hombre muy bueno pero muy tonto. Los de la clase alta son adversos al comercio y muy aficionados a la vida militar y a las intrigas en los asuntos de gobierno [...]. La clase baja detesta el trabajo y la subordinación, y parece preferir aproximarse a la vida salvaje que a la civilizada".

Subjetividad e intereses ingleses aparte, es posible leer entre líneas el impacto de las circunstancias en la mentalidad colonial. Años después (1828), el cirujano de la corbeta inglesa Chanticleer, W. H. Webster, anotaría en su informe - cuando se gestaba la Convención Preeliminar de Paz que daría la independencia a Uruguay - que: "Los grotescos vehículos usados como carros o carretas de ninguna manera insinúan en su carácter el cultivo de las artes y las ciencias. Estos vehículos primitivos [...] pertenecen a otras épocas idas hace mucho tiempo, pero, no obstante, los campesinos los conservan con todo el respeto que sus antepasados tuvieron antes de ellos y se oponen a todo progreso con obstinación" (Webster, 1828, p. 51).

Más allá del rechazo a las empresas y metodologías de trabajo industriales, es posible pensar que aquellos orientales más que a 
los vehículos se aferraban al recuerdo de mejores tiempos - "con todo el respeto que sus antepasados tuvieron" - y que sintieran desconfianza por "todo progreso" debido a los problemas que las intervenciones extranjeras habían generado. $\mathrm{Y}$ es de hacer notar que el mismo año en que Hood criticaba "el fraude, la mentira y el engaño" imperante en los orientales (1815). Larrañaga traslucía la pérdida de confianza en el otro - Viaje a Paysandú - pero en este caso en un comerciante inglés. En el trayecto de Mercedes a Paysandú su grupo se encontró con un comerciante que quiso convencerlos de la inminente llegada - a solo cinco días - de una expedición reconquistadora española. Fue tan insistente que despertó desconfianza y pronto, dice Larrañaga "comprendimos que lo que deseaba era que nuestra pobre gente malbaratase y vendiese por medio real los cueros y sebos, que era el objeto principal de su venida", y agrega: "Es necesario pues que sepan nuestros paisanos que ya no es tan común en el comercio aquella buena fe y probidad que aun en el día caracteriza a nuestros honrados hacendados" (Larrañaga, 1812, p. 25). La buena fe y honradez de otros tiempos ya no era tan común y comerciantes sin escrúpulos no vacilaban en engañar para beneficiarse. El hecho de que no se pudiera confiar en la palabra dada deja ver el cambio de actitudes que se operaba.

Probablemente los comentarios del alemán Samuel Burmeister (1832) tengan la misma raíz. Para él, las mujeres orientales ostentaban frescura solo en la adolescencia y luego pasaban a tener una actitud sin alma y vacía. Su principal deseo era casarse y no aspiraban a más: "La mujer ostenta su frescura sólo de los doce a los dieciséis años de edad y luego decae el encanto de la juventud, reemplazado por una típica actitud sin alma, sin vida, cuya vacuidad llama enseguida la atención del extranjero acostumbrado a tratar con las damas. Su principal deseo es contraer matrimonio lo antes posible y aquel con quien ya no es posible, pierde todo valor a los ojos de la mayoría de las jóvenes damas." (Burmeister, 1832, p. 32).

Si bien es posible explicar esta situación como mera percepción del viajero, también se puede entender como reflejo de la depresión social. La violencia, el vandalismo, las luchas entre caudillos y el rápido empobrecimiento generaron ese rechazo a lo foráneo que perduraría en Uruguay durante el siglo XIX. No extraña que tras la Guerra Grande (1851) se blandiera el lema "América para los americanos" ni que la prensa exigiera la independencia cultural del Uruguay (Revista Histórica, 1946, T. VI, p. 279). 


\section{Referencias}

APOLANT, J. A. Génesis de la familia uruguaya. Montevideo: I.H.G.U., 1966. ARREDONDO, H. El transporte a sangre en el antiguo Montevideo. 1959.

AZAROLA GIL, L. Los orígenes de Montevideo. 1607-1749. Montevideo, 1976. BARRÁN, P.; y NAHÚN, B. Un naturalista en el Plata. Montevideo, Prólogo. BENTANCUR, A. El puerto colonial de Montevideo. Montevideo: F.H.C.E., 1997.

FREGA, A. Tradición y modernidad en la crisis de 1808. Una aproximación al estudio de la Junta de Montevideo. Sociedad y cultura en el Montevideo colonial: FHCE-IMM, 1998.

LOCKHARDT, W. La vida cotidiana en la colonia. Montevideo: Arca, 1967.

ARAUJO, O. Diccionario histórico. Montevideo, 1944.

PIERROTTI, N. Leer, pensar y actuar. La influencia del libro en la mentalidad colonial montevideana. Madrid: Clío, 2004.

PIERROTTI, N. Las ciencias en la educación montevideana del siglo XVIII. Montevideo: Sociedad y cultura en el Montevideo colonial/FHCE-IMM, 1998.

SCHIAFFINO, R. Historia de la medicina en Uruguay. Montevideo: Instituto Histórico y Geográfico, 1937.

\section{Fuentes y documentos}

AGNA Buenos Aires 1814-15 - Acuerdos del extinto Cabildo de Buenos Aires Serie IV, t. 7, lib LXIX-LXXIV.

D’ORBINY, A. Voyage dans lÁmerique méridionale. Paris, 1839.

Documentos relativos a la Junta Montevideana de Gobierno de 1808. Junta Departamental. Montevideo, 1958.

ISABELLE, A. Viaje a la Argentina. Montevideo, 1832.

LARRAÑAGA, D. A. Viaje de Montevideo a Paysandú. Montevideo: Banda Oriental, 1997.

PARISH ROBERTSON, J. La Argentina en la época de la revolución. Londres, 1839.

PORTER, H. J. Memorias. Publicadas por Adrian Dexter. Londres, 1995.

The Southern Star. Montevideo, 1807.

WEBSTER, W. Narrative of a voyage to the Southern Atlantic Ocean in the years 1828, 29, 30..., apud Revista Tres, Montevideo, 12 de febrero 1999.

Recebido em 19 de julho de 2007. 